\title{
Penile Ischemia as a Complication of Epinephrine Use in Penile Nerve Block: Truth or Myth?
}

\author{
Muhammad Asykar \\ Palinrungi (D) \\ Andhini LR \\ Palinrungi $^{2}$ \\ Robert Christeven ${ }^{3}$ \\ Muhammad Faruk (iD ${ }^{3}$ \\ 'Division of Urology, Department of \\ Surgery, Faculty of Medicine, Hasanuddin \\ University, Makassar, South Sulawesi, \\ Indonesia; ${ }^{2}$ Department of Surgery, \\ Akademis Jaury Jusuf Putra Hospital, \\ Makassar, South Sulawesi, Indonesia; \\ ${ }^{3}$ Department of Surgery, Faculty of \\ Medicine, Hasanuddin University, \\ Makassar, South Sulawesi, Indonesia
}

Correspondence: Muhammad Asykar Palinrungi

Division of Urology, Department of Surgery, Faculty of Medicine, Hasanuddin University, Jalan Perintis Kemerdekaan KM II, Makassar, South Sulawesi, 90245, Indonesia

Tel +6282187776907

Fax $+624 I 158757 \mid$

Email apalinrungi@yahoo.com

\begin{abstract}
The administration of a local anesthetic agent with epinephrine is controversial in penile surgery because of necrosis risk resulting from prolonged vasoconstriction of terminal vessels. We reported a case of an 8-year-old boy suffering from ischemia in the glans of the penis and epidermolysis of the penile skin after circumcision with penile nerve block using anesthetic agents containing epinephrine. The addition of epinephrine to the anesthetic agent (lidocaine) in penile nerve block before circumcision remains controversial. It remains controversial because multiple factors can cause skin necrosis after the circumcision. The adverse effect of epinephrine use in circumcision remains unproven because of a lack of scientific evidence. The administration of epinephrine in penile surgery is the decision of the physician.
\end{abstract}

Keywords: penile ischemia, skin necrosis, nerve block, circumcision, anesthetic agents

\section{Introduction}

Local anesthetic agents generally aggravate epinephrine to reduce the concentration of agents in plasma, reducing the likelihood of systemic toxicity. Local anesthetic agents also improve the quality of anesthesia and simultaneously extend the duration of the peripheral nerve block. ${ }^{1}$ The administration of a local anesthetic agent with epinephrine is controversial in the surgery of end artery organs, such as the penis and fingers, because of the risk of necrosis resulting from prolonged vasoconstriction of terminal vessels. ${ }^{2}$ However, to our knowledge, no study has thoroughly demonstrated any disastrous effect of epinephrine use in penile nerve block in circumcision.

\section{Case Presentation}

An 8-year-old boy suffered significant swelling and blistering of his penis at 24-h postcircumcision. A medical practitioner performed the circumcision. The circumcision was performed using a sterile instrument and suture material (plain catgut 3/0) with circumcision technique and local anesthetic nerve block with lidocaine hydrochloride $20 \mathrm{mg} / \mathrm{mL}$ and epinephrine $12.5 \mathrm{mcg} / \mathrm{mL}$ per $2 \mathrm{~mL}$ ampoule. The anesthetic solution was administered using the penile nerve block technique. The pain sensation and swelling were apparent approximately $1 \mathrm{~h}$ after the circumcision and became prominent 3-4 h after circumcision. Five hours after the circumcision, the swelling had worsened, and a blister appeared at the skin of the penile corpus. At 24-h postcircumcision, the swelling had improved, but the blister remained (Figure 1). The penile glans was paler (an ischemic sign), with incarcerating crust. Proper wound care 


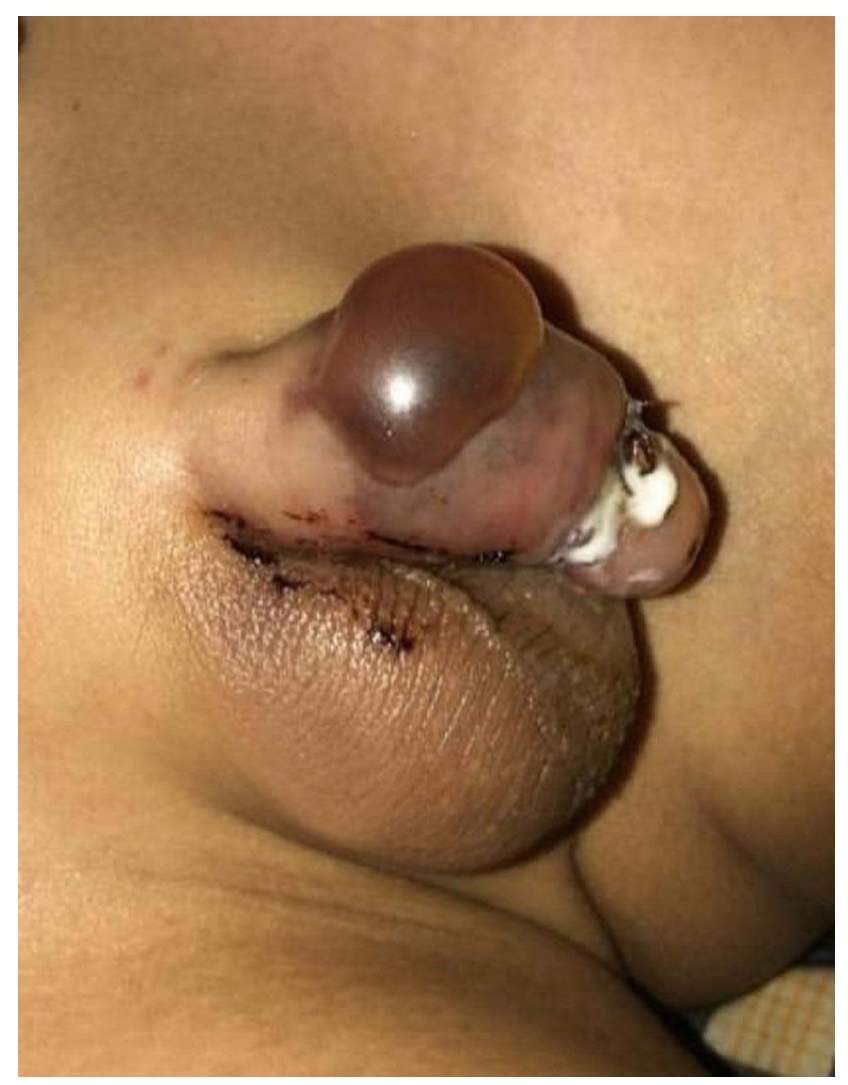

Figure I The blister appeared on the penile corpus $24 \mathrm{~h}$ after the circumcision.

with normal saline compress and wound crust cleansing was performed. On the second day after the circumcision, the blister had subdued, and the superficial ulcer was observed at the wound bed. On the third day, yellowish-necrotic tissue was observed on the lateral side of the glans (Figure 2). Neither gangrene nor pus was observed at the penis. One week after the circumcision, the wound at the glans and corpus was improved. Four months after the circumcision event, the penis had healed without any cicatrix (Figure 3). There was no disturbance in micturition or erection.

\section{Discussion}

Circumcision is a commonly performed procedure in childhood, especially in Indonesia. Failure (4-7\%) and complication (1.5-5\%) of circumcision can be caused by vascular disturbance, including vasospasm of the penile glans due to surgery or the dorsal penile nerve block, vascular obstruction secondary to the mass effect of anesthetic solution, hematoma at the site of injection, and endothelial injury. ${ }^{3}$

Anesthesia with peripheral nerve block is the most commonly used anesthesia method in circumcision. ${ }^{2}$ The addition of epinephrine to the anesthetic agent (lidocaine)

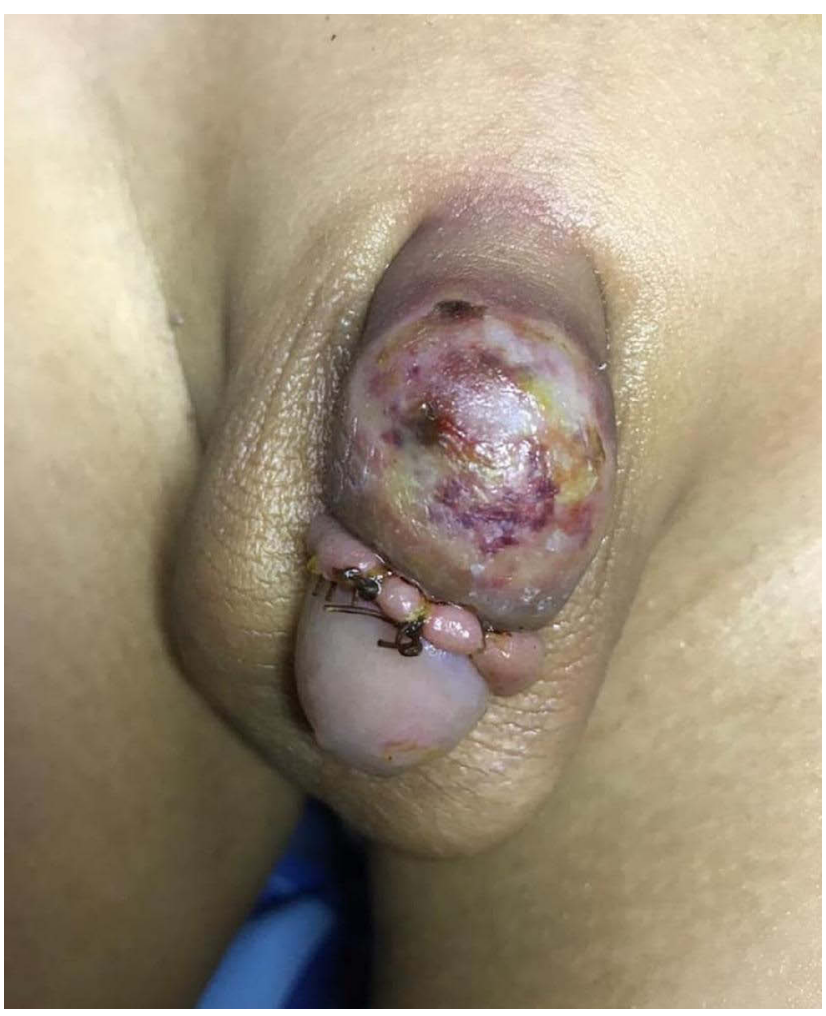

Figure 2 Superficial ulcer at the corpus, yellowish necrotic tissue at the glans, and crust were apparent.

in penile nerve block before circumcision remains controversial. Gul et al reported a case of scrotal skin necrosis as a suspected complication of epinephrine used in circumcision. Still, it remains controversial because multiple factors can cause skin necrosis after the circumcision. ${ }^{4}$ On the other hand, Garrido-Abad and Suarez-Fonseca reported a case of a 3-year-old boy who suffered glans necrosis after circumcision, which was not related to the use of epinephrine in peripheral nerve block (mepivacaine without epinephrine). ${ }^{3}$

The patient in our case had experienced blistering in the penile corpus skin as a sign of epidermolysis, which can be related to penile skin ischemia. However, it resolved spontaneously without any invasive intervention. In our case, the ischemia of the glans with necrotic tissue was probably caused by incarcerating crust/scab, which could also have happened in the other circumcision cases. It also improved with the treatment of saline compress and crust cleansing. There was no accurate evidence to link the ischemia with epinephrine use. The study by Schnabl et al showed that local anesthetics with epinephrine are safe for use in penile nerve block. ${ }^{2}$ 


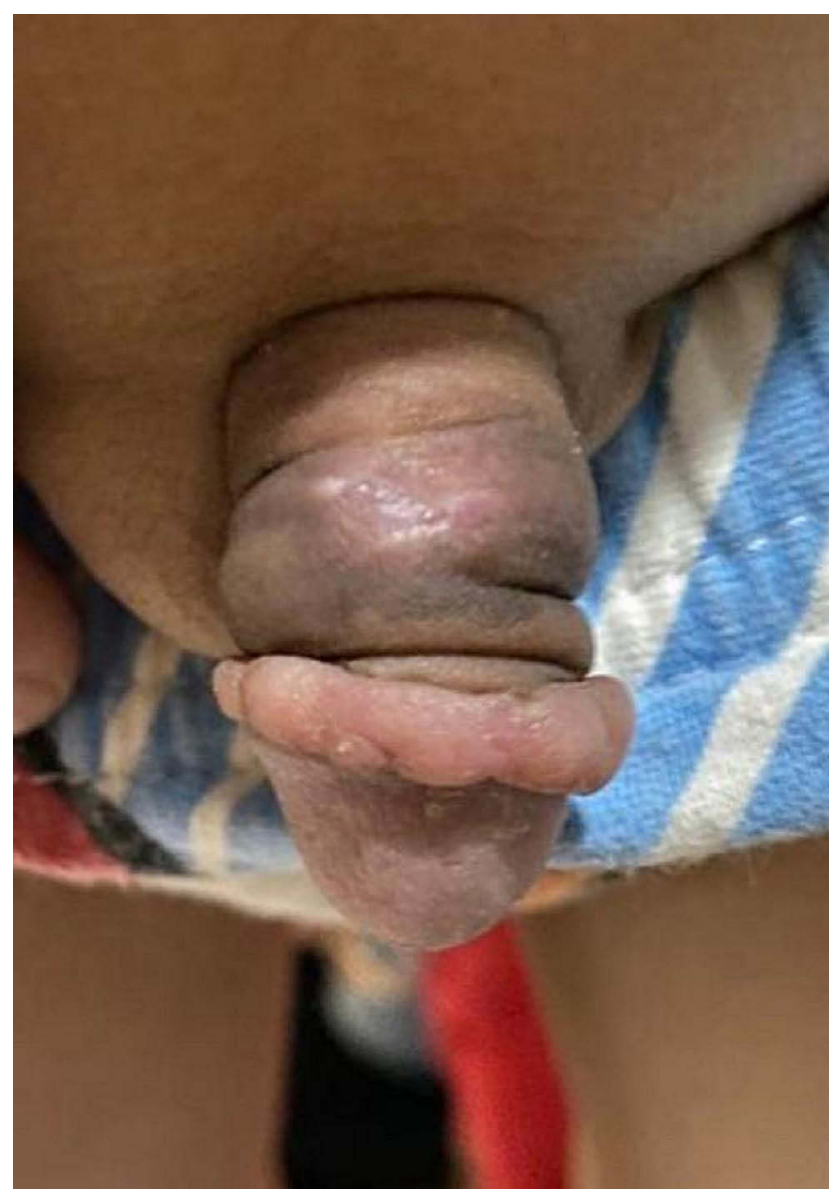

Figure 3 The penile wound healed 4 months after circumcision.

\section{Conclusion}

The penile ischemia event in the circumcision could not be confirmed as a complication related to epinephrine use in peripheral nerve block because it could have been caused by multiple factors. The adverse effect of epinephrine use in circumcision remains unproven because of a lack of scientific evidence. The administration of epinephrine in penile surgery is the decision of the physician.

\section{Ethical Approval}

The study is exempt from ethical approval in our institution.

\section{Consent}

Written informed consent was obtained from the parent/ guardian of the patient for publication of this case report and accompanying images. A copy of the written consent is available for review by the Editor-in-Chief of this journal on request.

\section{Disclosure}

The authors report no conflicts of interest for this work.

\section{References}

1. Sinnott CJ, Cogswell LP, Johnson A, Strichartz GR. On the mechanism by which epinephrine potentiates lidocaine's peripheral nerve block. Anesthesiology. 2003;98(1):181-188. doi:10.1097/00000542200301000-00028

2. Schnabl SM, Herrmann N, Wilder D, Breuninger H, Häfner HM. Clinical results for use of local anesthesia with epinephrine in penile nerve block. $J$ der Dtsch Dermatologischen Gesellschaft. 2014;12 (4):332-339. doi:10.1111/ddg.12287

3. Garrido-Abad P, Suarez-Fonseca C. Glans ischemia after circumcision and dorsal penile nerve block: case report and review of the literature. Urol Ann. 2015;7(4):541. doi:10.4103/0974-7796.164862

4. Gul M, Kaynar M, Sekmenli T, Ciftci I, Goktas S. Epinephrine injection associated scrotal skin necrosis. Case Rep Urol. 2015;2015:3. doi: $10.1155 / 2015 / 187831$

\section{Publish your work in this journal}

Research and Reports in Urology is an international, peer-reviewed, open access journal publishing original research, reports, editorials, reviews and commentaries on all aspects of adult and pediatric urology in the clinic and laboratory including the following topics: Pathology, pathophysiology of urological disease; Investigation and treatment of urological disease; Pharmacology of drugs used for the treatment of urological disease. The manuscript management system is completely online and includes a very quick and fair peer-review system, which is all easy to use. Visit http://www.dovepress.com/ testimonials.php to read real quotes from published authors. 